\title{
A new specie of Stenotabanus (Stenochlorops) (Diptera: Tabanidae) from Amazonas, Brazil, and a key to the subgenus
}

\author{
J. A. Rafael (') \\ G. B. Fairchild ${ }^{(2)}$ \\ I. S. Goarayeb ( $\left.{ }^{3}\right)$
}

\begin{abstract}
Description and figures are given for Stenotabanus (Stenochlorops) bequaerti $\mathrm{n}$. $\mathrm{sp}$. from Amazonas, Brazil. Figures are included for paradoxus (Lutz) and vitripennis (Lutz), and a key to the subgenus is provided.
\end{abstract}

\section{INTRODUCTION}

Fairchild (1969) erected the subgenus Steriotabanus (Stenochlorops) to encompass species with subcallus and face largely bare and shiny, eye with slender green lines forming two narrow transverse loops, and scutellum contrastingly pale haired. In this subgenus are included: Diachlorus paradoxus Lutz, 1913; D. vitripenis Lutz, 1913, type specie of subgenus; and one undescribed species treated as paradoxus Lutz by Bequaert (1926:224). This last species is here described and a key to the subgenus is furnished.

\section{KEY TO STENOTABANUS (STENOCHLOROPS) FEMALES}

1. Frons clearly divergent at base (figs. 3a, 5a); frontal index, 1.4-1.5; costal cells yellowish; subcallus castaneous $\ldots \ldots \ldots \ldots \ldots \ldots \ldots \ldots, 2$

1'. Frons convergent at base (fig. 1a); frontal index between 2.6-2.8; costal cells hyaline (fig. 1d); subcallus black. (Brazil : Amazonas) ........ ................. S. bequaerti n. sp.
2. Length of scape approximately half the basal width of frons; palpi much inflated basally, clearly shorter than height of frons (figs. 5a, b) (Brazil: Mato Grossc) ........ S. paradoxus (Lutz)

2'. Scape shorter, about $1 / 3$ basal width of frons; palpi slender, as long as height of frons; (figs. 3a, b) (Brazil: Ceara) .......... S. vitripennis (Lutz)

\section{Stenotabanus (Stenochlorops) bequaerti n. sp.} (Figs. 1a-e, 2a-e)

Diachlorus paradoxus, Bequaert, 1926: 224 (misid.).

A small, shiny blackish species with hyaline wings, bicolored legs and yellow pilose scutellum.

FEMALE: body length, $6.2 \mathrm{~mm}$; wing length $5.4 \mathrm{~mm}$. Eyes bare, pattern (in life) dark with two narrow green transverse loops, these margined with red (fig. 1e). Frons (fig. 1a) about 2.7 times as high as basal width, slightly wider at vertex than at base; tubercle on vertex with vestiges of 3 ocelli; basal callus black, shiny, protuberant, as wide as frons, with a shiny median upper ridge (median callus) connected to ocellar tubercle Middle of frons with median area blackish in certain lights, otherwise sparsely whitish pollinose. Subcallus black, shiny. Frontoclypeus and gena black, shiny, with sparse beard blackish. Tentorial pits whitish pollinose. An-tenna (fig. 1b) thinly pollinose; the scape and pedicel brown, black haired; flagellum brown, basally more or less orange yellow, the style

(1) - Instituto Nacional de Pesquisas da Amazônia, Manaus.

(2) - University of Florida, Gainesville, USA.

(3) - Museu Paraense Emílio Goeldi, Belém. 

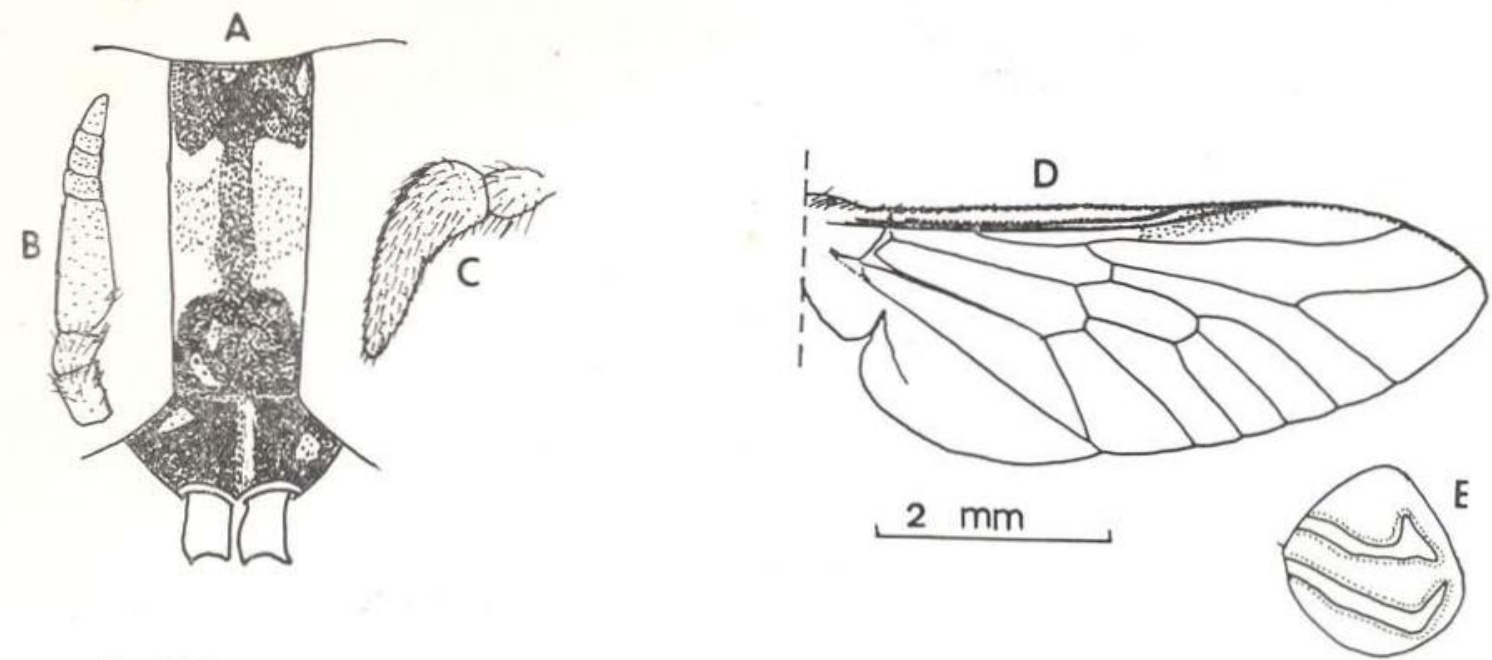

$1 \mathrm{~mm}$

Fig. 1 - Stenotabanus bequaerti n. sp. a) frons; b) antenna; c) palp (holotype of); d) wing; e) eye pattern (paratype ㅇ).

much darker. Palpi (fig. 1c) black, shiny. clothed with long black hairs basally and shorter black hairs apically. Proboscis slightly longer than palpi, labella soft, blackish, thinly pollinose.

Mesonotum black, shiny, with scattered irridescent, greenish scalelike hairs when fresh; scutellum dark at base with caudal $2 / 3$ bearing dense, pale yellow, scalelike hairs; mesopleura black, shiny; mesoanepisternum with higher coricentration of irridescent scales on postero-dorsal margin; coxae, trochanter and femora blackish, black haired; protibia with basal $2 / 3$ white, blackish distally; mesoand metatibia all whitish exsept for a pale brown ring on distal portion; protarsi black; meso- and metatarsi with basitarsi whitish. darker toward apex; haltere chestnut brown; wing with basicosta bare, pruinose, venation normal, wholly hyaline, except the stigma pale brown, nervures yellowish, no appendix at fork of third vein (fig. 1d).

Abdomen completely black and shiny, sparsely short black-haired, except for longer, sparse white hairs laterally and ventrally on last few segments. Genitalia: tergites VIII, IX, $X$ and cerci as, in fig. 2a. Hypoproct (fig. 2b) with fine subapical hairs, a basal median strip less sclerotized and lateral margins without sclerotization. Eighth sternite and gonapophyses (fig. 2c) with rounded base and bilobed apex. Genital fork (fig. 2d) with wide basal incision; spinous bristles of genital comb very distinct and strong. Basal portion of spermathecal ducts well sclerotized. Spermatheca (fig. 2e) slightly enlarged and more sclerotized apically.

MALE: not known.

Distribution: Brazil, Amazonas.

MATERIAL EXAMINED: Holotype $q$, labelled Brasil, Amazonas, BR 174, km 170, 04.IX. 1979, J.D. Charlwood coll. Deposited in the Systematic Entomology Collection of I.N.P.A., Manaus.

Paratypes: all from the state of Amazonas, Brazil. 40 우, same data as above; 2 \%, Manaus, Rio Negro, 11.IX.1978, J. A. Rafael coll.; $2 \% \div$, Manaus, Reserva Ducke, 15.IX.1978, J. A. Rafael coll.: 2 ㅇ, Manaus, Campus Univ., 17.VIII.1978, malaise trap, J. A. Rafael coll.; $1 \%$, Manaus, Campus Univ., 11.VIII.1979, J. A. Pafael coll.; 1 \% , Estrada BR 17 (probably 174), km 38, Manaus, E. V. Silva coll., no 2913; 13 ㅇ. Rio Nambu (Inhambu), tributary of Rio Negro, 01.IX.1969, F. Almeida e A. Faustino coll., no 2925; 1 \%. Lago Urini, 29. VIII.1979, Robin Best coll.: 1․ Manaus, Reserva Biolog. Campina, 15. iX.1975, L. P. Albuquerque coll.; $10 \%$. Rio Demeni, Buiaçu até Lago Ipiranga, no homem, VIil. 1978, A. Faustino coll.: 
$15 \div \%$. Manaus, Rio Cuieiras, 17.X.1978, J. Dellome coll.; 25 \% ?, Rio Japurá. 4.IX.1980, Victor Py coll.; 1 \%, Manaus, Ceplac, 28.VII.1977, I. S. Gorayeb coll.

Paratypes to be deposited at INPA and in the collections of G. B. Fairchild: Museu Paraense Emílio Goeldi, Belém, Pará; Instituto Oswaldo Cruz, Rio de Janeiro and Museu de Zoologia. São Paulo.

Most collections of this species have been made near the mouth of the Rio Negro, but the distribution extends much further west, to
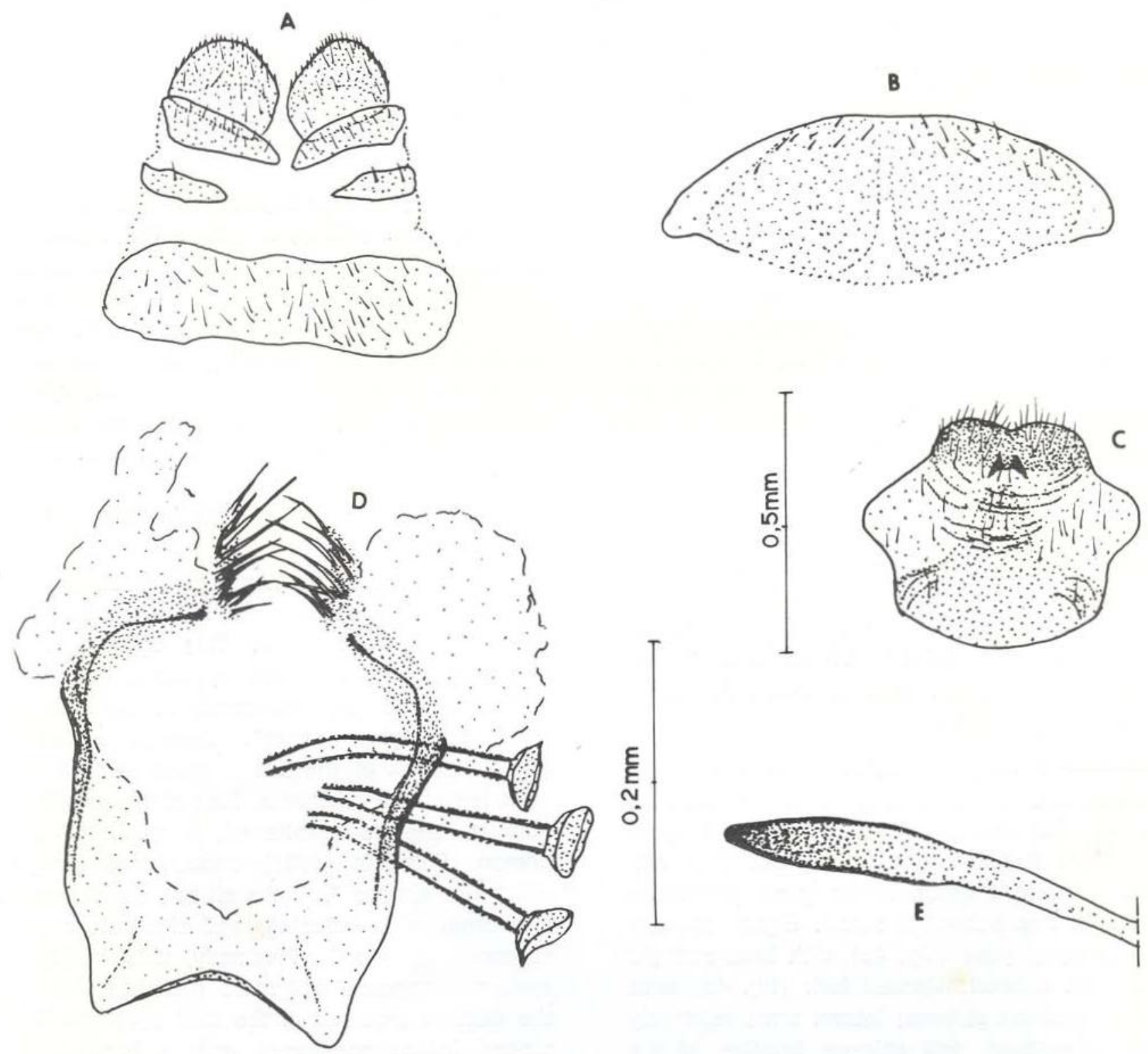

Rio Naınbu (Igarapé Inhambu), Rio Demeni, upper Rio Negro, Lago Urini (Rio Juruá) and Rio Japurá.

Before it was formally described, autogeny was reported in Stenotabanus bequaerti $\mathrm{n}$. sp. by Charlwood \& Rafael (1980), who dissected more than 200 females of this species captured during August to October. This seems to be the period of maximum flight activity for this species in the studied area, and agrees with label data from specimens captured in other years and localities.

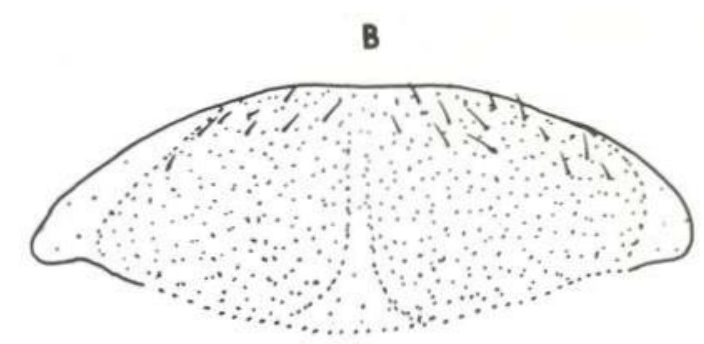

Fig. 2 - Genitalia of Stenotabanus bequaerti n. sp. a) VIII, IX, X tergites and cerci; b) hypoproct; c) VIH sternite and gonapophyses; d) genital fork and basal portion of spermathecal ducts; e) spermatheca (paratype $q$ ). 
A

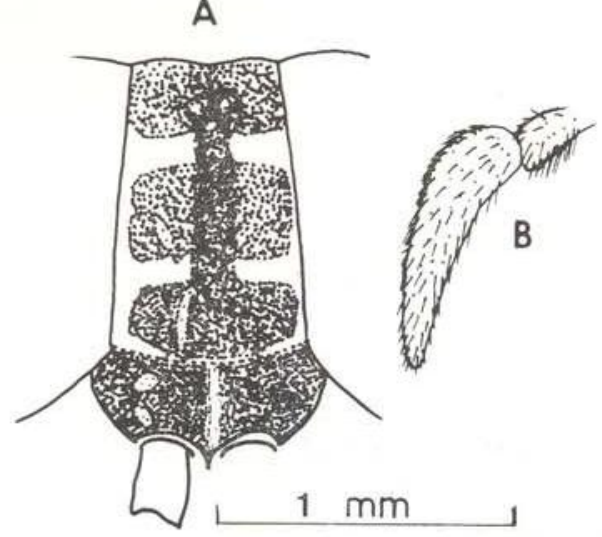

Fig. 3 - Stenotabanus vitripennis (Lutz) a) frons; b) palp (paratype $q$ ).

Stenotabanus (Stencchlorcps) vitripennis (Lutz) (Figs. 3a-b, 4a-d)

Diachlorus vitripennis Lutz, 1913: 161-162, PI. 12, fig. 11; Fairchild, 1961: 213.

Stenotabanus (Stenochlorops) vitripennis, Fairchild, 1969; 215; Fairchild, 1971: 50.

Only the figured structures are here described. These figures complement the original description of Lutz which omits, or does not represent adequately, such structures as are needed for a good characterization of the species.

HEAD : Frons (fig. 3a) divergent at base, basal callosity protuberant, narrower than frons lateral margins pollinose. Subcallus castaneous, shiny, protuberant. Antennal scape about $1 / 3$ basal width of frons. Palpi (fig. $3 b$ ) castaneous, with pilosity of the same color, slender, as long as height of frons. Antennae missing.

GENITALIA : Tergites VIII, IX and X with shape, pilosity and pigmentation as represented in fig. $4 a$. The cercus represented in this figure is broken at mid-length. Hypoproct (fig. 4b) with a small, distinct, medio-apical projection and with fine subapical setae. Eighth sternite and gonapophyses (fig. 4c) with base straight and apex bilobed. Genital fork (fig. 4d) with medial incision at base; lateral arms relatively well sclerotized, and spinous bristles of the genital comb mistinct, though less so than in the preceding species (S, bequaerti). Basal portion of spermathecal ducts well sclerotized.
Two paratypes of this species (T-280 and T-282) were received for study from Instituto Oswaldo Cruz. These specimens arrived badly damaged in the mail. The associated parts were giued to the insect. However, when this was not pcssible, parts were mounted on slides and received the same label as the pinned insect. The original description of this species was based on six specimens collected in Quixada (Ceara State) .

\section{Stenotabanus (Stenechlorops) paradoxus (Lutz)} (Figs. 5a, b)

Diachlorus paradoxus Lutz, 1913: 160-161, PI. 13, fig. 15; Bequaert, 1926; 224 (misid.); Kröber, 1928; 100 1934: 257; Fairchild, 1961: 213.

Stenotabanus (Stenochlorops) paradoxus, Fairchild, 1969; 215; Fairchild, 1971: 50.

The originai description of this species given by Lutz (1913), is good. The figure of the frons and palpi are givan here to better characterize it. Frons (fig. 5a) divergent at base, median callosity not clearly visible, basal callosity narrower than frons. lateral margins pollinose. Subcallus dark castaneous, shiny protuberant. Scape castaneous, its length approximately half basal width of frons. Palpi (fig. 5b) basally inflated, castaneous, with slightly paler hairs, clearly shorter than height of frons.

The genitalia are not figured, since the abdomen has been damaged since the time of the original description. This species was described from a single specimen that appeared altered "in consequnce of the attacks of a destroying insect". Damage included complete lack of the left leg and part of the right leg of the prothorax, lack of the antenna! flagella, and as mentioned, a mutilated abdomen. Fairchild (1961) encountered a type still more altered "It lacks all but one leg, and one antenna is missing, and the colors are obscured by glue". Presently, this holotype specimen appears still more damaged, due to the damage incurred in the mail systems. The pinned insect possesses only a headland a thorax. On the head, only the palpi, both scapes and the pedicel of only one antenna are present. On the thorax, only the right metathoracic leg 
and halteres remain. The wings, labella, and some abdominal fragments are mounted on slides. (lam. T-277).

\section{Comparative notes}

St. (Stenochlorops) bequaerti n. sp. is most similar to St. (Stenochlorops) vitripennis (Lutz), described from Ceara. It appears to differ from vitripennis in having wholly trans. parent wings, without the darkened extreme base of the wing, or yellowish costal cell shown by Lutz (1913). It also has a black subcallus apparently brown in vitripennis, and the frons is narrower and more convergent at base in the new species. According to Lutz' figure
(1913, Est. 12, fig. 11) shiny scale like hairs are !ess abundant on the scutellum of vitripennis than on the new species. The unique eye pattern of vitripennis is like that of the new species. Comparison with Lutz' holotype and his description and figure of his Diachlorus paradoxus indicates that it is also similar, but has a much wider frons and different eye pattern than either vitripennis or bequaerti. Fairchild (1961) discussed the types of both Lutz' species and noted that both differed from a specimen reported by Bequaert as paradoxus from lower Rio Negro, and another which he saw in Instituto Oswaldo Cruz from Rio Japura, Ducke coll. The Rio Negro specimen has been compared and it is the same as the
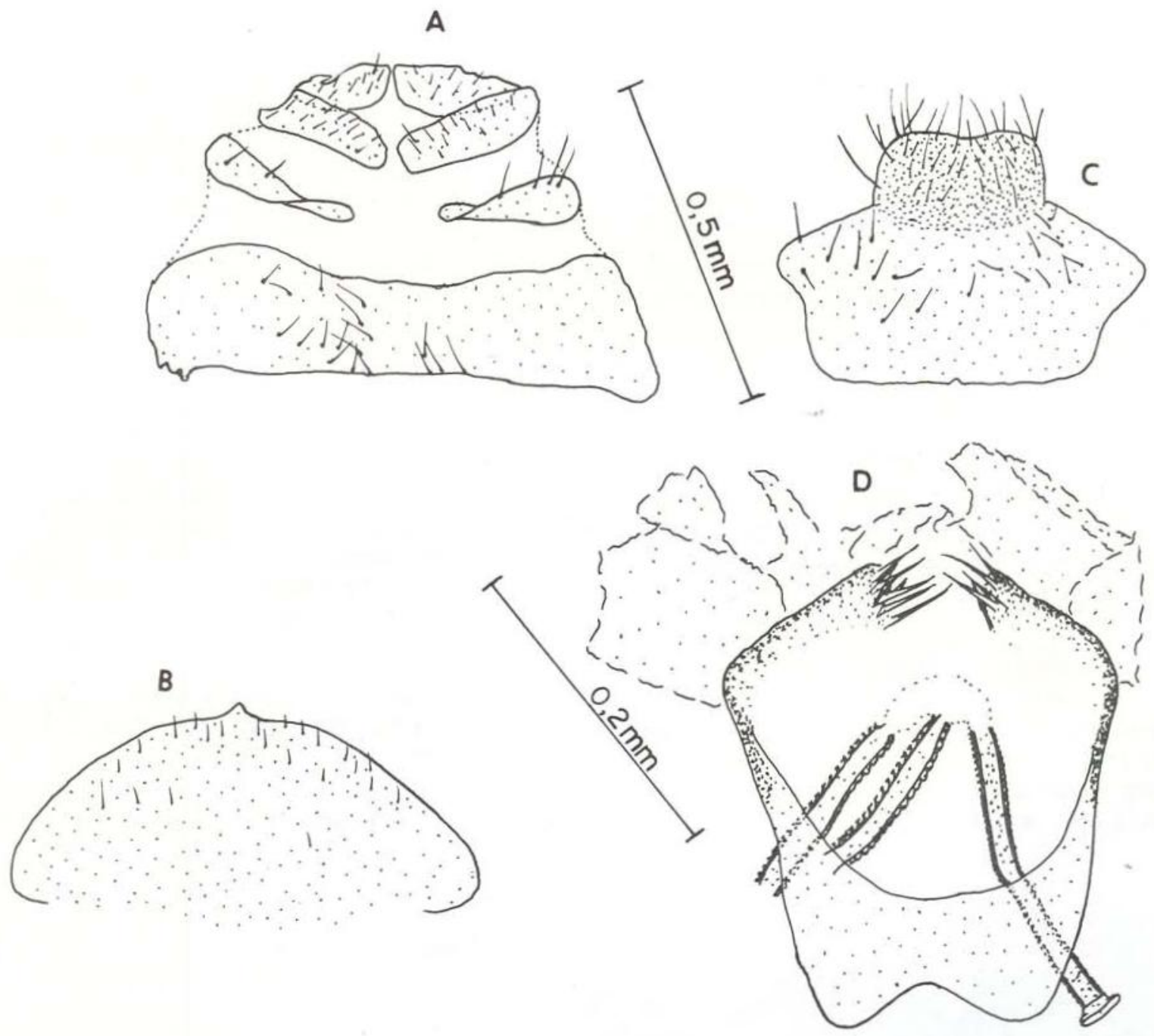

Fig. 4 - Genitalia of Stenotabanus vitripennis (Lutz) a) VIII, IX, X tergites and cerci; b) hypoproct; c) VIII sternite and gonapophysis; d) genital fork and basal portion of spermathecal ducts. (paratype ?). 


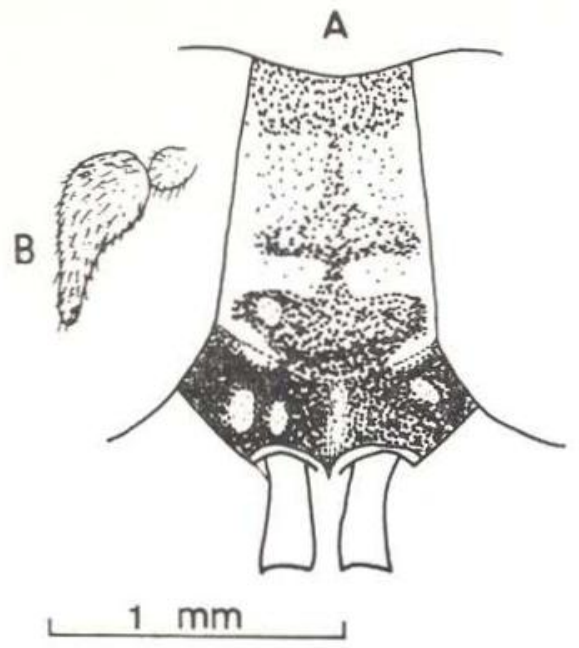

Fig. 5 - Stenotabanus paradoxus (Lutz) a) frons; b) palp (holotype o ).

present series from Amazonas. Both Bequaert (1926) and Kröber (1928) thought that Lutz species were synonymous and the former used paradoxus for his specimens from Rio Negro, Amazonas. Fairchild (1969) erected the subgenus Stenotabanus (Stenochlorops) for these three species, with Diachlorus vitri. pennis Lutz as type.

\section{AGRADECIMENTOS}

The authors are indebted to Dr. Leonidas Deane of the Instituto Oswaldo Cruz. Rio de Janeiro for the loan of material, and Dr. Victor Py-Daniel, of INPA for orientation in the prepa. ration of genitalia.

\section{SUMÁRIO}

Stenotabanus (Stenochlorops) bequaerti $\mathrm{sp}$. n. do Amazonas, Brasil, é descrita e figurada. São incluídas figuras para vitripennis (Lutz) e paradoxus (Lutz) e uma chave é dada para o subgênero.

\section{REFERENCES}

BEQUART, J.

1926 - Tabanidae. In: Strong et al., Medical Report of the Hamilton Rice seventh expedition to the Amazon, in conjuction with the Departamesnt of Tropical Medicine of Harvard University. Contrib. n. IV. Harvard Inst. Trop. Biol. Med., Chap. XV, Incesta. pp. 214-235. Cambridge, Harvard Univ. Press.

CHARLWOOD, J.D. \& RAFAEL, J.A.

1980 - Antogeny in the River Negro horse fly, Lepiselaga crassipes, and an undescribed species of Stenotabanus (Stenochlorops) (Diptera: Tabanidae) from Amazonas Brazil. J. Med. Ent., 17: 519-521.

FAIRCHILD, G.B.

1961 - The Adolpho Lutz collection of Tabanidae (Diptera). I. The described genera and species, condition of the collection, and selection of lectotypes. Mem. Inst. Osw. Cruz, 59 (2): 185-249.

1969 - Notes on neotropical Tabanidas. XII. Clasfication and distribution, with keys to genera and subgenera. Arq. Zool., São Paulo, 17 (4): 199-255.

1971 - A catalogue of the Diptsra of the Americas South of the United States 28. Family Tabanidae. Museu de Zoologia, Univ. São Paulo. 163pp.

KP.ÖBER, O.

1928 - Die Amerikanischen Arten der TabanidenSubfamilie Diachlorinae End. Arch. f. Schiffs.-u. Tropen Hyg., 32 (2): 1-55.

1934 - Catalogo dos Tabanidae da América do Sul e Central, incluindo o México e as AntiIhas. Rev. Entom., Rio de Janeiro, 4 (2-3): 222-276, 291-333.

LUTZ, A.

1913 - Tabanidas do Brasil e alguns Estados vizinhos. Mem. Inst. Osw. Cruz, 5 (2): 142191.

(Aceito para publicação em $13 / 10 / 81$ ) 